\title{
VIPERIDAE SNAKE BITE: KASUS SERIAL
}

Alfi Rizky Medikanto, Lothar Matthaeus Manson Vanende Silalahi, Sri Sutarni, Cempaka Thursina Srie Bagian Neurologi Fakultas Kedokteran Universitas Gadjah Mada

Korespondensi: alfirizkym@gmail.com

\begin{abstract}
ABSTRAK
Latar Belakang: Gigitan ular merupakan salah satu kegawatdaruratan medis dan penyakit akibat okupasi yang sering diabaikan oleh tenaga medis, paramedis maupun pemangku kebijakan kesehatan sehingga sangat terbatas untuk dipelajari karena sistem pelaporan yang lemah. Ular golongan Viperidae sering ditemukan di wilayah Asia Tenggara memiliki bisa dengan kandungan hematotoksin dengan mekanisme aktivasi faktor koagulasi, trombositopenia, hiperfibrinolisis, dan koagulasi intravaskular luas.

Laporan Kasus: Dilaporkan dua kasus gigitan ular golongan Viperidae. Kasus pertama seorang pria, 73 tahun datang dengan gigitan ular pada pergelangan kaki kiri. Pasien mengalami penurunan kesadaran, anemia, koagulopati, insufisiensi renal, dan perdarahan saluran kemih. Pemeriksaan funduskopi dan CT scan kepala tidak didapatkan perdarahan. Kasus kedua adalah seorang pria, 58 tahun datang dengan gigitan ular pada pergelangan kaki kanan. Pasien mengalami penurunan kesadaran, anemia, gangguan fungsi hati, koagulopati, perdarahan saluran kemih, dan hiponatremia.

Kesimpulan: Manifestasi klinis gigitan ular Viperidae dapat berefek pada sistem koagulasi dan jika tidak ditangani dengan tepat dapat menyebabkan gangguan sistem saraf pusat, kardiovaskular dan urogenital.
\end{abstract}

Kata Kunci: snake bite, Viperidae, koagulopati, anemia, penurunan kesadaran, perdarahan saluran kemih. 


\title{
VIPERIDAE SNAKE BITE: CASE SERIES
}

\author{
Alfi Rizky Medikanto, Lothar Matthaeus Manson Vanende Silalahi,Sri Sutarni, \\ Cempaka Thursina Srie \\ Neurology Department of Medical Faculty of Gadjah Mada University \\ Corespondence: alfirizkym@gmail.com
}

\begin{abstract}
Background: Snake bite is one of public health burden that gives a long term morbidity and mortality. Snake bite is one of medical emergency and occupational disease that often neglected by medics, paramedics, health policy, so that the avaliable resources about this case is scarce because of weak reporting. Viperidae groups snake often found in Southeast Asia region could have venom that contain hematotoxin content with mechanism of coagulation factor activation, thrombocytopenia, hyperfibrinolysis, and disseminated intravascular coagulation.

Case Report: Reported two Viperidae snake bite cases. First case, male 73 years old, bited on his left foot. The patient got decrease of consciousness, anaemia, coagulopathy, renal insufficiency, and urinary bleeding. No hemorrhagic found on funduscopy and Head CT Scan examination. Second case was male, 58 years old, bited on his right foot. The patient got decrease of consciousness, anaemia, impaired liver function, coagulopathy, urinary bleeding, and hyponatraemia.

Conclusion: Viperidae snake bite primarily affect the coagulation system and if neglected also affect cardiovascular system, central nervous system and urogenital system
\end{abstract}

Keywords: snake bite, Viperidae, coagulopathy, anaemia, decrease of consciousness, urinary bleeding. 


\section{LATAR BELAKANG}

Ular berbisa dapat ditemukan hampir di seluruh dunia (termasuk di lautan), kecuali pada beberapa pulau, lingkungan yang beku dan pada tempat dengan ketinggian ekstrim. Kasus kematian maupun keracunan akibat gigitan ular, merupakan masalah kesehatan masyarakat yang penting. Di beberapa lokasi, penderita gigitan ular mengalami morbiditas dan mortalitas yang cukup tinggi karena akses terhadap pelayanan kesehatan yang buruk, suboptimal dan pada waktu tertentu mengalami kesulitan dalam persediaan anti-bisa yang merupakan satu-satunya terapi spesifik. ${ }^{1}$

Ditemukan jumlah yang cukup besar penderita yang selamat setelah gigitan ular dengan disabilitas secara fisik yang besar karena nekrosis jaringan dan disabilitas secara psikis juga memperberat keadaaan. Efeknya cukup besar tetapi gigitan ular belum mendapatkan perhatian oleh tenaga kesehatan maupun pemangku kebijakan kesehatan sehingga dapat dikategorikan sebagai penyakit tropis yang terabaikan. ${ }^{1}$

\section{Kasus 1}

Seorang pria usia 73 tahun datang ke UGD setelah mengalami

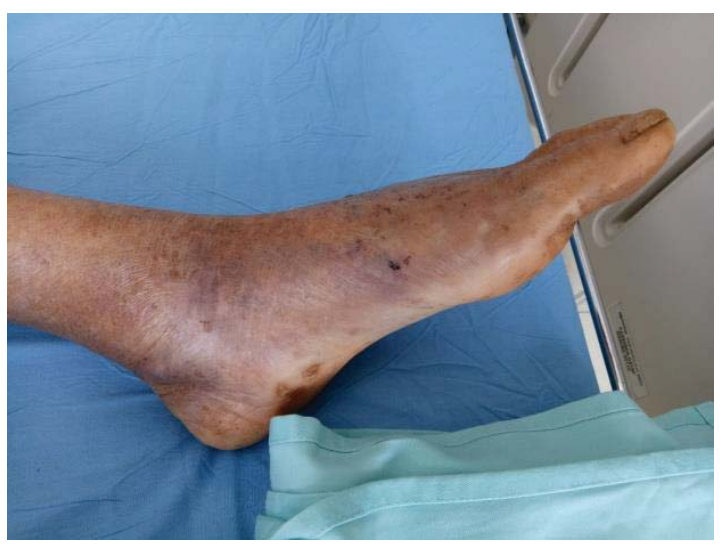

a gigitan ular. Dua hari sebelum masuk rumah sakit pasien digigit ular pada pergelangan kaki kiri saat mencari rumput untuk makanan ternak. Ular berwarna hijau dengan ekor berwarna merah, biasa disebut ular luwuk. Pasien mengalami gigitan ular satu kali, kemudian mual dan muntah berulang. Pasien mengikat pergelangan kaki pasien di atas gigitan dengan ilalang. Setengah jam berikutnya, pasien gelisah dan agak sulit diajak komunikasi, kemudian dibawa ke Puskesmas dan dirujuk ke UGD RS terdekat.

Saat di RS, pasien diberi anti bisa ular. Hari kedua perawatan pasien mengeluhkan nyeri perut bawah kanan dengan gejala mual dan muntah serta nyeri di tempat gigitan ular untuk penanganan lebih lanjut maka pasien dirujuk ke RS Sardjito.

Di UGD RS Sardjito, pasien tampak lemah dan somnolen. Tekanan darah 80/60 $\mathrm{mmHg}$, nadi 90x/menit, suhu $36^{\circ} \mathrm{C}$, pernapasan $22 \mathrm{x} /$ menit dengan skala nyeri pada tempat gigitan ular 8. Dari pemeriksaan fisik didapatkan anemi konjungtiva, nyeri tekan abdomen regio kanan bawah, edema, hematom pada pergelangan kaki kiri di sekitar tempat gigitan dan hematuria.

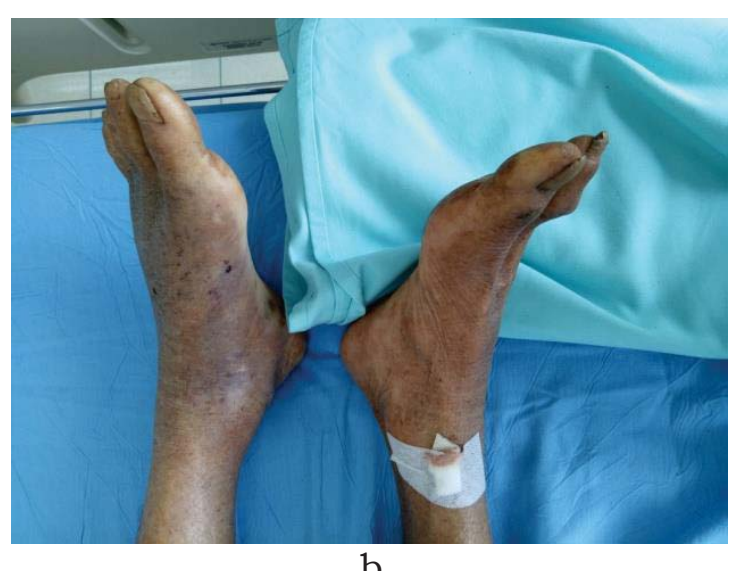

Gambar 1. Tempat Gigitan Ular.

a. Bruising disekitar gigitan. b.Perbandingan dengan kaki kanan 
Hasil laboratorium yang abnormal: anemia (hemoglobin 8,72), trombositopenia (44.000), hemodilusi (hematokrit 15,9 \%), insufisiensi renal (BUN 50, kreatinin 5,18), Ddimer 11.040 dan pemanjangan diastase perdarahan (PPT: 44,8, INR: 4,09, APTT: 105,5).

Pasien di diagnosis dengan snake bite grade III, syok hipovolemia, anemia kecurigaan blood loss, trombositopenia, acute kidney injury dan DIC. Dilakukan resusitasi cairan dan transfusi darah. Pemeriksaan funduskopi, Rontgen Toraks, USG abdomen dan CT scan kepala untuk mengetahui kemungkinan perdarahan internal. Setelah dilakukan resusitasi cairan, tekanan darah menjadi 120/80, kesadaran pasien komposmentis namun keluhan nyeri perut kanan bawah masih dirasakan.

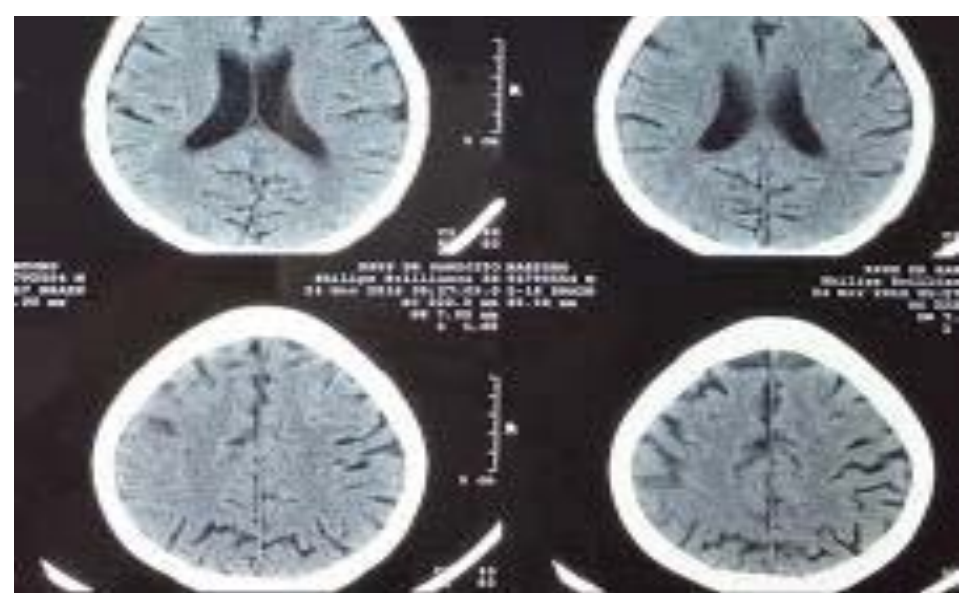

Gambar 2. Foto Head CT scan.

Hasil CT scan kepala tampak atrofi serebri tanpa adanya edema, perdarahan pada parenkim, subaraknoid maupun ventrikel.

\section{Kasus 2}

Seorang pria usia 58 tahun datang ke UGD setelah dua hari sebelumnya pasien digigit ular pada pergelangan kaki kanan saat sedang mencari rumput di sekitar rumahnya. Gigitan satu kali, nyeri hebat di kaki kanan. Beberapa menit kemudian pasien muntah satu kali, tidak menyemprot.

Satu jam kemudian, pasien diberi anti bisa ular. Pada hari kedua perawatan, mengeluh nyeri kaki kanan terutama di tempat gigitan ular. Kaki bengkak dari ujung hingga pangkal paha disertai perubahan warna kulit dan benjolan berisi cairan di sekitar bekas gigitan. Pasien BAK berwarna merah dan didapatkan trombositopenia (7000), leukositosis (AL 16,1 ribu), dan anemia (hemoglobin 11,4). Pasien dirujuk ke RS Sardjito, lemah agak bingung. Tanda-tanda vital didapatkan tekanan darah 100/60 $\mathrm{mmHg}$, nadi 86x/ menit, suhu $36,5^{\circ} \mathrm{C}$, pernapasan $20 x /$ menit dengan skala nyeri di tempat gigitan ular 8-9. Dari pemeriksaan fisik didapatkan edema tungkai kanan hingga kaki kanan, perubahan warna kulit dan benjolan berisi cairan pada pergelangan kaki kanan di sekitar tempat gigitan serta hematuria. Hasil laboratorium didapatkan anemia (hemoglobin 8), trombositopenia (3.000), leukositosis (AL 16,12 ribu), gangguan fungsi hati (SGOT161, SGPT 50), pemanjangan diastase perdarahan (PPT: >180, INR: $>20$, APTT: >180), dan hiponatremia (Na 128). 
Pasien di diagnosis dengan snake bite grade IV, gross hematuria, anemia kecurigaan blood loss, trombositopenia dan DIC. Dilakukan perawatan luka, pemberian ulang anti bisa, antibiotik, analgetik, infus $\mathrm{NaCl}$ 0,9\%, vitamin $\mathrm{K}$ dan transfusi darah. Rontgen Torak untuk kemungkinan infeksi paru dan usul CT scan kepala untuk kemungkinan perdarahan otak. Setelah perawatan selama satu hari, angka leukosit menurun (14,46 ribu), anemia memberat (hemoglobin 4,4), waktu pembekuan darah membaik (PPT 13,5; APTT 24,6), tekanan darah 120/60 mmHg, kesadaran kompos mentis namun nyeri kaki kanan bawah sudah berkurang (NPS 5-6).

Hasil rontgen thorak adalah pulmo tak tampak kelainan dan besar cor normal.

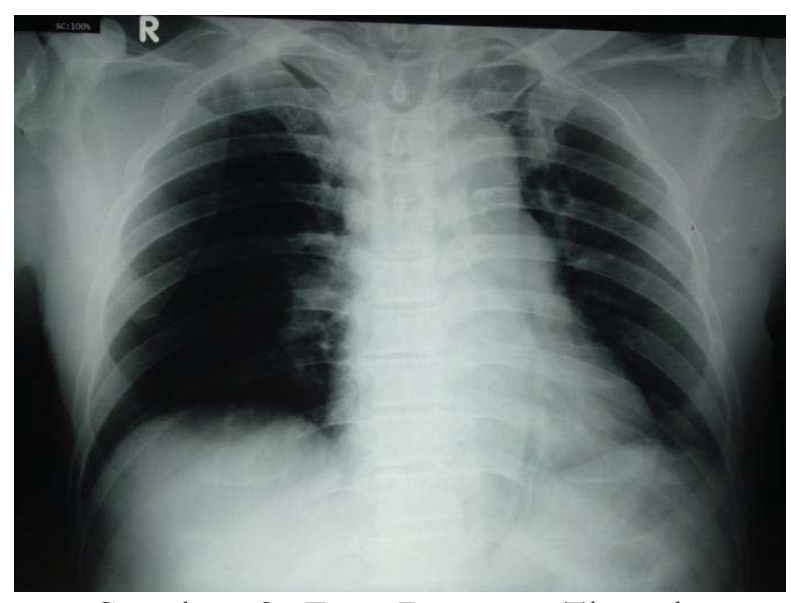

Gambar 3. Foto Rontgen Thorak.
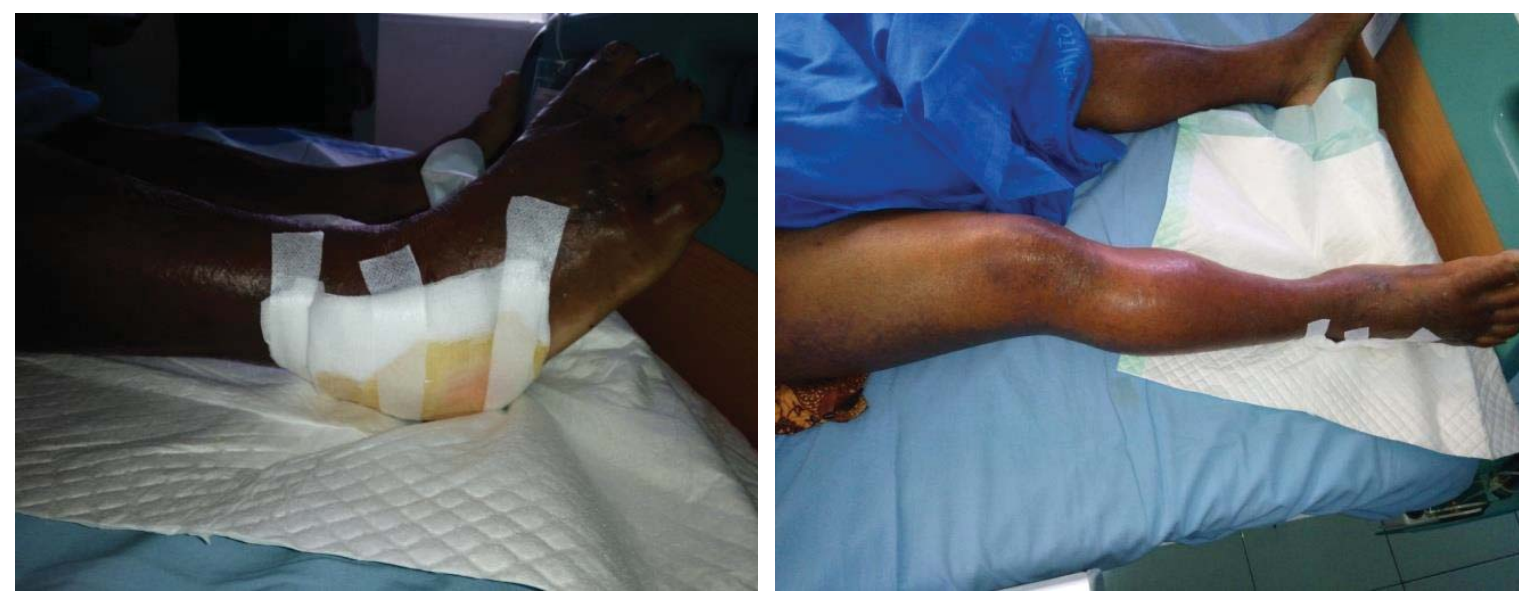

Gambar 4. Foto kaki kanan pasien saat di RSS (22/11/16). 

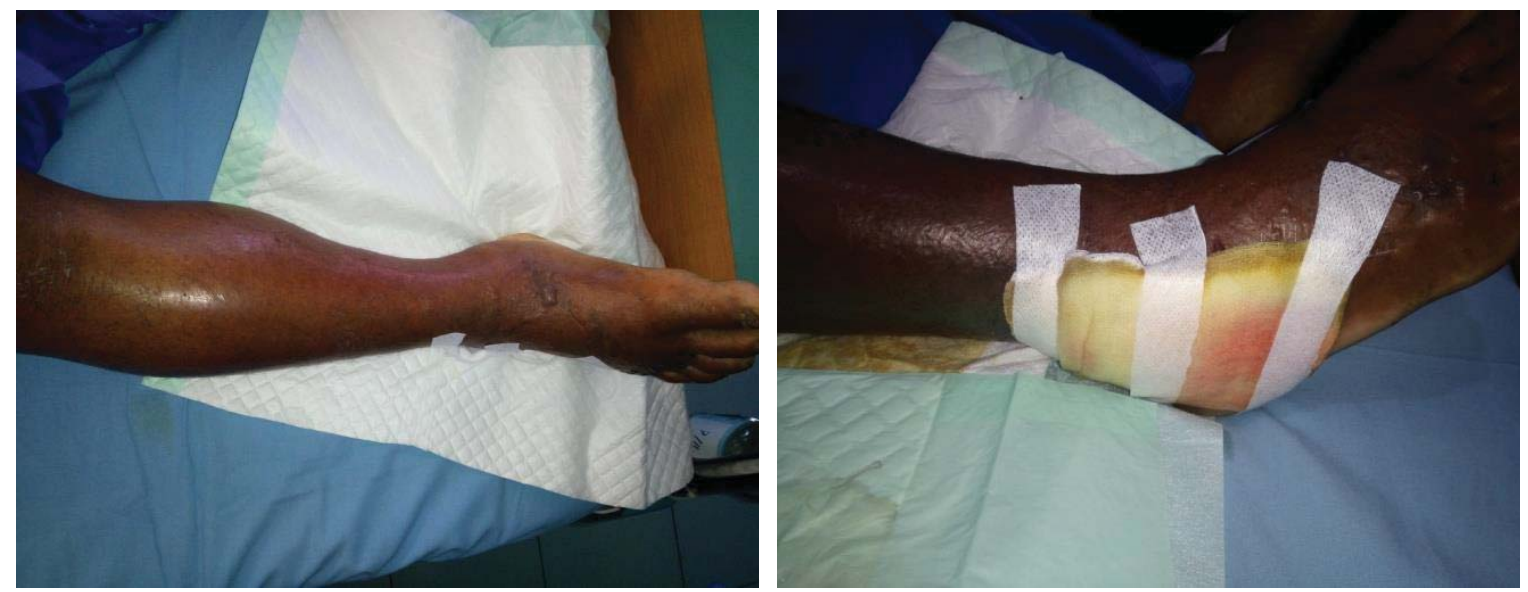

Gambar 5. Foto kaki kanan pasien saat di RSS (23/11/16).

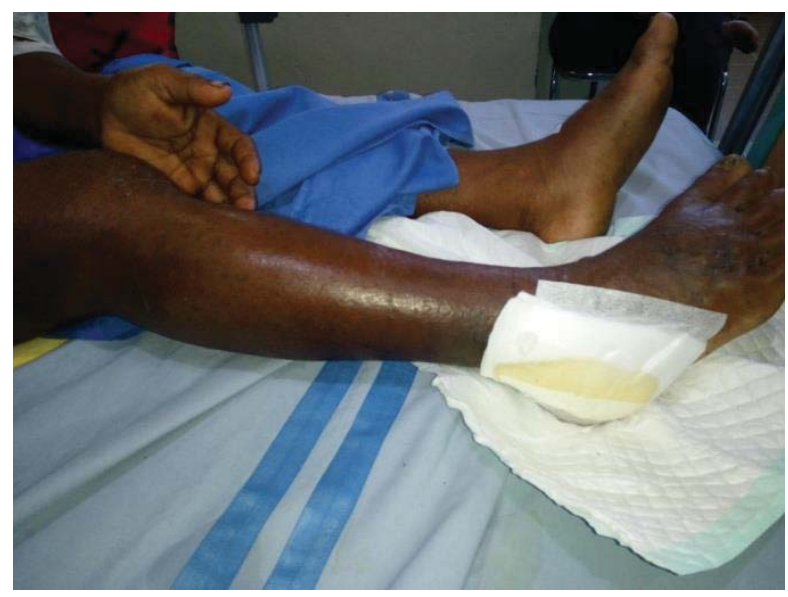

Gambar 5. Foto kaki kanan pasien saat di RSS (24/11/16).

\section{PEMBAHASAN}

\section{Epidemiologi}

Kasus gigitan ular di Asia Tenggara belum terdata dengan baik karena lebih banyak ditangani secara tradisional. Pada tahun 2008, diperkirakan 237.379-1.184.550 kasus gigitan ular, dengan kasus kematian 15.385-57.636 (1,3\%4,86\%) di daerah Asia Pasifik. Di Asia Selatan memiliki kematian akibat gigitan ular paling tinggi dengan perkiraan 14.112-33.666 kematian dengan $\quad 0,912-2,175 \quad(0,0027 \%-$ 0,0064\%) kematian/100.000/ tahun. Berdasarkan jumlah ini, 12-50\% kasus gigitan ular terjadi di Asia. ${ }^{1}$

Laki-laki umumnya lebih sering terkena dibanding perempuan, kecuali pada tempat pekerjaan yang didominasi perempuan seperti perkebunan kopi dan teh. Usia puncak terkena adalah usia anak dan dewasa muda dengan puncak case fatality pada usia dewasa muda dan tua. Pada wanita hamil gigitan ular dapat berisiko pada janin dan ibu karena efek perdarahan dan aborsi. Gigitan ular paling banyak bertempat di tungkai bawah dan pergelangan kaki para pekerja. ${ }^{2}$

\section{Ular Di Asia Tenggara}

Di Asia Tenggara, terdapat 3 famili ular berbisa yaitu: ${ }^{2}$

1. Elapidae: memiliki taring yang relatif pendek pada bagian depan. Contoh yang termasuk famili ini adalah kobra. Elapidae berbentuk relatif panjang, tipis dan memiliki warna yang relatif sama dengan sisik lebar dan halus pada bagian dorsal kepala. Beberapa spesies kobra dapat mengeluarkan taringnya dari 
jarak 1 meter atau lebih ke arah yang dianggap berbahaya.

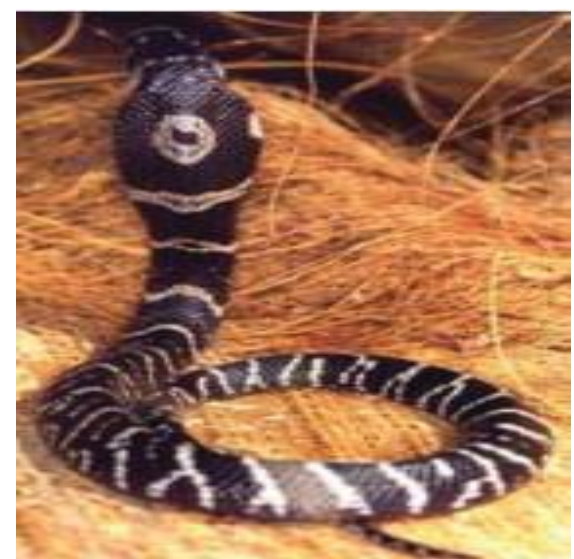

Gambar 6. Salah satu yang termasuk famili Elapidae.

2. Vipiridae: memiliki taring yang panjang yang secara normal terlipat pada rahang atas, namun dapat muncul ketika ular akan menyerang. Viperidae memiliki

tubuh pendek, namun tebal dengan sisik kecil dan kasar di bagian dorsal kepala yang membentuk pola warna pada seluruh bagian dorsal tubuh.

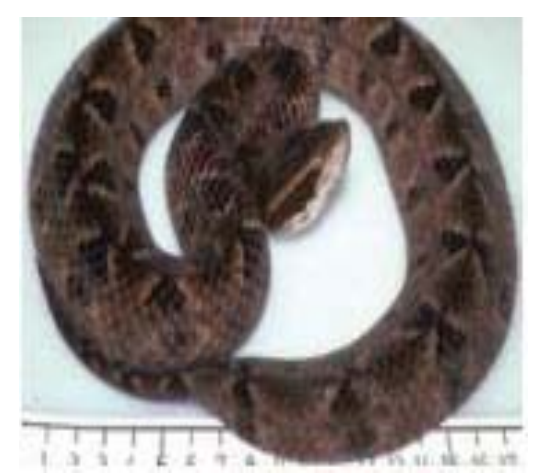

Gambar 7. Salah satu yang termasuk famili Viperidae.

3. Colubridae: dua spesies yang penting yang telah teridentifikasi adalah Rhabdophis subminiatus dan R. Tigrinus. Sesuai deskripsi dan istilah lokal yang sering digunakan, maka ular yang menggigit pasien 1 termasuk dalam viperidae dengan nama ilmiah Trimeresurus albolabris. 


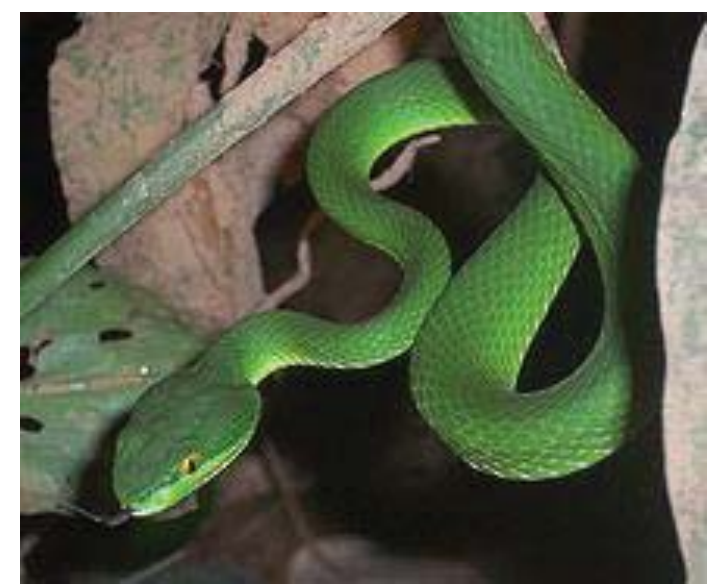

Gambar 8. Ular luwuk Trimeresurus albolabris.

Berdasarkan 3 famili diatas, ular yang memiliki pola dan corak yang sesuai dengan yang menggigit pasien 2 termasuk dalam vipiridae, subfamili crotalinae dengan nama latin Calloselasma rhodostoma.

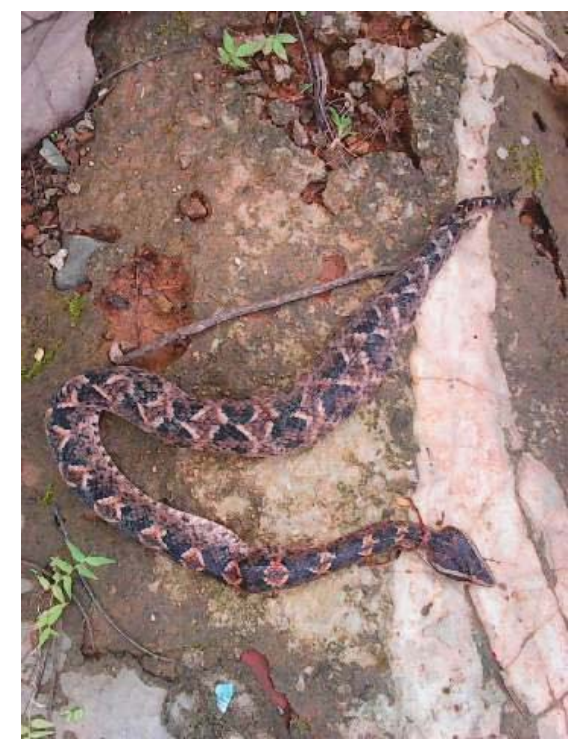

Gambar 9. Calloselasma rhodostoma.

\section{Manifestasi Klinis}

Racun adalah zat atau senyawa yang masuk ke dalam tubuh dengan berbagai cara yang menghambat respon pada sistem biologis dan dapat menyebabkan gangguan kesehatan, penyakit, bahkan kematian. Di sekeliling kita ada racun alam yang terdapat pada beberapa tumbuhan dan hewan. Salah satunya adalah gigitan ular berbisa yang sering terjadi di daerah tropis dan subtropis.
Bisa adalah suatu zat atau substansi yang berfungsi melumpuhkan mangsa dan sekaligus berperan pada sistem pertahanan diri. Bisa tersebut merupakan ludah yang termodifikasi, yang dihasilkan oleh kelenjar khusus. Kelenjar yang mengeluarkan bisa merupakan suatu modifikasi kelenjar parotid yang terletak di setiap bagian bawah sisi kepala di belakang mata. Bisa ular tidak hanya terdiri atas satu substansi tunggal, tetapi merupakan campuran kompleks, terutama 
protein, yang memiliki aktivitas enzimatik.

Efek toksik bisa ular saat menggigit tergantung spesies, ukuran ular, jenis kelamin, usia, dan efisiensi mekanik gigitan: apakah hanya satu atau kedua taring menusuk kulit, serta banyaknya serangan yang terjadi.

Saat menggigit, jumlah bisa ular yang masuk ke tubuh tergantung jenis ular, efisiensi secara mekanis, penetrasi taring pada kulit dan frekuensi gigitan. Inefisiensi mekanik dan ketidakmampuan ular mengontrol pengeluaran bisa membuat gigitan ular berbisa tidak selalu mengeluarkan racun yang berefek klinis. Sekitar $50 \%$ gigitan Malayan Pit Viper dan Russel's Pit Viper, 30\% gigitan kobra dan $5-10 \%$ gigitan viper tidak menghasilkan gejala. Ular tidak pernah menghabiskan cadangan bisa, bahkan walaupun pada serangan berulang dan ular menjadi relatif kurang berbisa setelah memakan mangsa. Ular ukuran besar cenderung mengeluarkan bisa lebih banyak di setiap gigitan, namun ular berukuran kecil kemungkinan banyak mengandung komponen berbahaya pada bisa yang mampu mempengaruhi hemostasis. ${ }^{2}$

Orang yang tergigit ular dapat mengalami gejala hebat bahkan ketika bisa ular tidak masuk tubuh. Orang yang terlalu cemas mengalami rasa ekstremitas seperti tertusuk, kaku pada tangan dan kaki serta gangguan keseimbangan. Beberapa kasus lain dapat menimbulkan syok vasovagal dan kolaps dengan detak jantung melambat. Penderita juga dapat mengalami agitasi, sensitif, peningkatan tekanan darah dan denyut nadi, gemetar dan berkeringat. Tanda dan gejala lain dapat berupa efek terapi awal yang diberikan. Tornikuet pada pertolongan darurat dapat menyebabkan nyeri, bengkak dan kongesti. ${ }^{2}$
Nyeri akibat penetrasi gigi pada permukaan kulit dapat meningkat dengan deskripsi berdenyut atau menusuk. Pembengkakan dapat secara bertahap meluas ke arah proksimal. Pembesaran limfonodi regional dan limfadenopati dapat dirasakan, namun pada beberapa jenis ular, rasa nyeri mungkin tidak ada sehingga menyebabkan pembengkakan lokal yang terabaikan. Tanda dan gejala yang terjadi dapat bersifat lokal maupun umum. ${ }^{2}$ Gejala lokal antara lain bekas gigitan, nyeri lokal, perdarahan lokal, bengkak, kebiruan, abses, dan nekrosis. Gejala umum yang dapat timbul adalah mual, muntah, syok, pingsan, malaise, nyeri perut, hipotensi dan aritmia jantung.

\section{Patofisiologi}

Komposisi bisa ular 90\% adalah protein. Setiap bisa ular dapat mengandung lebih dari 100 protein yang berbeda: enzim $(80-90 \%$ pada viperidae dan $25-70 \%$ pada elapidae), polipeptida toksin non-enzim dan protein non-toksin seperti nerve growth factor. Bisa ular mengandung enzim hidrolase, hialuronidase dan aktivator maupun penghambat proses fisiologis seperti kiniogenase. Kebanyakan venom mengandunglamino acid oxidase, phosphomonodan diesterases, 5'-nucleotidase, DNAase, NAD-nucleosidase, phospholipase A2 and peptidases ${ }^{2}$. Selain protein, komponen lain yang dapat ditemuk-an dalam bisa ular adalah lemak, polisakarida, riboflavin, histamin dan serotonin. ${ }^{3}$

1. Zinc Metalloproteinase Haemorrhagins: memiliki efek menghancurkan endotel vaskular, menyebabkan perdarahan.

2. Enzim prokoagulan: Bisa ular Vipiridae dan beberapa Elapidae dan Clubridae memiliki protease serin dan enzim prokoagulan lain yang memiliki struktur seperti 
trombin yang mengaktivasi faktor $\mathrm{X}$, protrombin dan faktor pembekuan lain. Enzim ini menstimulasi pembekuan darah dengan pembentukan fibrin pada aliran darah. Secara paradoks, proses ini berujung pada ketidakmampuan darah berkoagulasi karena banyak fibrin yang dihasilkan langsung diurai oleh plasmin tubuh dan kadangkadang dalam 30 menit dari gigitan, kadar faktor pembekuan sangat menurun (koagulopati konsumtif) menyebabkan darah tidak akan membeku. Beberapa bisa ular juga memiliki faktor antihemostatik. Bisa Uar Viper Russel memiliki toksin yang mengaktivasi faktor V, X, IX dan XII, fibrinolisi, Protein C, agregasi trombosit, antikoagulasi dan perdarahan.

3. Phospolipase $\mathbf{A}_{2}$ (lechitinase): merupakan enzim yang banyak dipelajari pada bisa ular. Enzim ini menghancurkan mitokondria, sel darah merah, leukosit, trombosit, akhiran serabut saraf, otot lurik, endotel vaskular dan membran lain. Enzim ini menghasilkan aktivitas neurotoksin presinaptik, efek sedasi seperti opiat yang akan menyebabkan pelepasan histamin dan zat antikoagulan.

4. Asetilkolinesterase: ditemukan pada bisa Elapidae, enzim ini tidak memberikan efek neurotoksitas.

5. Hialuronidase: memberikan efek penyebaran bisa pada jaringan. Enzim ini termasuk enzim proteolitik (metaloproteinase, endopeptidase atau hidrolase) dan sitotoksin polipeptida (kardiotoksin) yang akan meningkatkan permeabilitas vaskular yang berakibat edema, pembentukan bula dan nekrosis tempat gigitan.
Bisa ular juga mengandung neurotoksik dengan cara kerja: 1) Post sinaps; a-bungarotoksin dan cobrotoksin, yang terdiri dari 60-74 asam amino, toksin ini terikat ke reseptor asetilkolin pada motor end plate. 2) Presinaptik; $\beta$ bungarotoksin, crotoksin dan taipoksin, mengandung 120-140 asam amino dan subunit fosfolipase A. Toksin ini mengeluarkan asetilkolin pada akhiran syaraf pada neuromuscular junction dan merusak akhiran saraf dan mencegah pengeluaran neurotransmitter berikutnya.

Golongan Viperidae terdiri dari beberapa jenis yang hidup di daerah Asia Tenggara seperti Russell's viper (Daboia spp), Malayan pit viper (Calloselasma rhodostoma), dan green pit viper (Cryptelytrops albolabris dan $C$ macrops/ Trimeresurus spp). Golongan ini dikenal sebagai ular berbisa yang mengandung hematotoksin namun dengan mekanisme yang berbeda. Bisa Russell's viper mengaktivasi faktor $\mathrm{V}$ dan X serta dapat menyebabkan disseminated intr-avascular coagulation (DIC). Bisa Calloselasma spp dan Trimeresurus spp memiliki efek thrombin-like yang menyebabkan hipofibrinogenemia, trombositopenia, dan hiper-fibrinolisis. ${ }^{4}$

\section{PENATALAKSANAAN}

Monitor severitas dan progresifitas gejala klinis akibat bisa ular penting dalam penatalaksanaan namun sangat sulit. Alat ukur yang telah ada adalah severity score system, digunakan untuk mengkuantifikasi severitas gejala klinis sehingga dalam monitoring dapat lebih akurat. Sangat direkomendasikan skor ini dinilai pada 6, 12 dan 24 jam setelah admisi rumah sakit. ${ }^{5}$ 


\section{Pertolongan Pertama}

Telah banyak cara yang dilakukan untuk melakukan pertolongan pertama penderita gigitan ular Pit Viper, namun tidak satupun yang mampu mencegah morbiditas dan mortalitas. ${ }^{6}$ Follow up jangka panjang menunjukkan individu kehilangan kemampuan gerak di area yang tergigit dan efek negatif lain akibat pertolongan pertama seperti robekan, hisapan, bebatan.

Prinsip dalam penanganan pertama adalah tidak menambah efek buruk. Salah satu penelitian tentang penderita yang diberikan pertolongan pertama maupun yang belum menunjukkan bahwa tidak ada bukti berbeda dalam luaran jangka pendek. ${ }^{4}$

Pertolongan pertama yang harus dihindari adalah es, insisi, suction, torniquet (memperburuk edema) dan penghangatan. Penanganan pertama yang direkomendasikan adalah membuat penderita tetap tenang, menjaga agar tempat gigitan berada lebih rendah dari posisi jantung dan rujuk penderita ke fasilitas kesehatan yang tepat. Pasien harus diawasi dengan ketat dalam minimal 8 jam dari saat gigitan pertama dengan evaluasi snake bite severity score. Efek bisa ular bergantung waktu. Penundaan dalam melakukan penanganan awal akan merugikan penderita dan menimbulkan komplikasi yang ireversibel.

\section{Penanganan Lanjutan}

\section{Survei primer dan resusitasi}

Prinsip penanganan "ABCDE' secara umum meliputi: ${ }^{2}$

1) Airway.

2) Breathing (pergerakan nafas).

3) Circulation (pulsasi arteri).

4) Disability nervous system (kesadaran).

5) Exposure and Enviromental Control (perlindungan dari dingin, risiko tenggelam).
Beberapa kondisi khusus yang membutuhkan penanganan segera antara lain:

1) Hipotensi/ syok: dapat sebagai efek langsung pada sistem kardiovaskular atau sebagai efek sekunder dari hipovolemia, pelepasan substansi vasoaktif, perdarahan maupun reaksi anafilaksis akibat bisa ular.

2) Gagal nafas akibat efek neurotoksik bisa yang melumpuhkan otot pernafasan.

3) Penurunan kondisi tiba-tiba akibat pelepasan torniquet yang telah dipasang.

4) Cardiac arrest akibat hiperkalemia karena rabdomiolisis akibat efek bisa ular pada sistem otot.

5) Pasien yang terlambat penanganannya dapat terjadi gagal ginjal akut, septikemia dan nekrosis lokal di daerah yang terkena gigitan.

Berdasarkan panduan penanganan racun ular berbisa di Indonesia langkah-langkah yang harus diikuti pada penatalaksanaan gigitan ular adalah: ${ }^{7}$

1) Pertolongan pertama, harus segera dilakukan secepatnya setelah terjadi gigitan ular sebelum korban dibawa ke rumah sakit. Hal ini dapat dilakukan oleh korban sendiri atau orang lain yang ada di tempat kejadian. Tujuan pertolongan pertama adalah menghambat penyerapan bisa, mempertahankan hidup korban dan menghindari komplikasi sebelum mendapatkan perawatan medis di rumah sakit serta mengawasi gejala dini yang membahayakan. Segera bawa korban ke tempat perawatan medis. 
Pertolongan yang dilakukan adalah menenangkan korban yang cemas, imobilisasi bagian tubuh yang tergigit dengan cara mengikat atau menyangga dengan kayu agar tidak terjadi kontraksi otot (karena pergerakan atau kontraksi otot dapat meningkatkan penyerapan bisa ke dalam aliran darah dan getah bening), pertimbangkan pressureimmobilization pada gigitan Elapidae, hindari gangguan terhadap luka gigitan karena dapat meningkatkan penyerapan bisa dan menimbulkan perdarahan lokal.

2) Korban harus segera dibawa ke rumah sakit secepatnya, dengan cara yang aman dan senyaman mungkin. Hindari pergerakan atau kontraksi otot untuk mencegah peningkatan penyerapan bisa.

3) Pengobatan gigitan ular Pada umumnya terjadi salah pengertian mengenai pengelolaan gigitan ular. Metode penggunaan torniket (diikat dengan keras sehingga menghambat peredaran darah), insisi (pengirisan dengan alat tajam), pengisapan tempat gigitan, pendinginan daerah yang digigit, pemberian antihistamin dan korti-kosteroid harus di-hindari karena tidak terbukti manfaatnya.

4) Terapi yang dianjurkan meliputi:

a. Bersihkan bagian yang terluka dengan cairan faal atau air steril.

b. Untuk efek lokal dianjurkan imobilisasi menggunakan perban katun elastis dengan lebar $\pm 10 \mathrm{~cm}$, panjang
$45 \mathrm{~m}$, yang dibalutkan kuat di sekeliling bagian tubuh yang tergigit, mulai dari ujung jari kaki sampai bagian yang terdekat dengan gigitan. Bungkus rapat dengan perban seperti membungkus kaki yang terkilir, tetapi ikatan jangan terlalu kencang agar aliran darah tidak terganggu. Penggunaan torniket tidak dianjurkan karena dapat mengganggu aliran darah dan pelepasan torniket dapat menyebabkan efek sistemik yang lebih berat.

c. Tindakan pendukung berupa stabilisasi yang meliputi penatalaksanaan jalan nafas, penatalaksanaan fungsi pernafasan, sirkulasi, resusitasi perlu dikakukan bila kondisi klinis korban berupa hipotensi berat dan shock, shock perdarahan, kelumpuhan saraf pernafasan, kondisi yang tiba-tiba memburuk akibat terlepasnya penekanan perban, hiperkalemia akibat rusaknya otot rangka, serta kerusakan ginjal dan komplikasi nekrosis lokal.

d. Pemberian suntikan antitetanus, atau bila korban pernah mendapatkan toksoid maka diberikan satu dosis toksoid tetanus.

e. Pemberian suntikan penisilin kristal sebanyak 2 juta unit secara intramuskuler.

f. Pemberian sedasi atau analgesik untuk meng- 
hilangkan rasa takut cepat mati/ panik.

g. Pemberian serum antibisa. Karena bisa ular sebagian besar terdiri atas protein, maka sifatnya adalah antigenik sehingga dapat dibuat dari serum kuda. Di Indonesia, antibisa bersifat polivalen, yang mengandung antibody terhadap beberapa bisa ular. Serum antibisa ini hanya diindikasikan bila terdapat kerusakan jaringan lokal yang luas.

\section{Terapi Spesifik}

Terapi spesifik gigtan ular adalah dengan pemberian antibisa ular, suatu imunoglobulin yang diekstrak dari plasma kuda, keledai maupun domba yang telah diimunisasi degan pemberian bisa ular. Antibisa ular ada 2 jenis yaitu:

1. Monovalen: antibisa yang menetralkan bisa ular spesies spesifik.

2. Polivalen: antibisa yang dapat menetralkan bisa ular dari beberapa spesies yang sering muncul pada area geografis tertentu.

Antibisa ular yang banyak dikembangkan adalah yang polivalent yang menetralkan bisa ular jenis neurotoksik Elapidae (Naja kaouthia, O. hannah, Bungarus candidus, $B$. fasciatus) and haematotoksik Viperidae (Daboia siamensis, Calloselasma rhodostoma, Cryptelytrops- Trimeresurusalbolabris). Indikasi pemberian anti-bisa ular:

1. Abnormalitas hemostasis: terdapat manifestasi perdarahan secara klinis dan koagulopati (PT dan PTT abnormal, trombosit < 100.000).

2. Tanda neurotoksik (ptosis, optalmoplegia, paralisis).

3. Abnormalitas kardiovaskular (hipotensi, syok, aritmia, EKG abnormal).

4. Gagal ginjal akut: oliguria/ anuria, peningkatan BUN dan kreatinin.

5. Hemoglobinuria/ mioglobinuria; produk urin kecoklatan, nyeri hebat pada otot.

6. Pembengkakan lokal yang melibatkan lebih dari setengah ekstremitas yang tergigit dalam 48 jam atau pembengkakan setelah gigitan pada jari.

7. Penambahan bengkak yang cepat, dalam beberapa jam.

8. Pembesaran limfonodi dan nyeri tekan limfonodi yang menjadi drainase tempat gigitan.

Pemberian antibisa ular harus sesegera mungkin diberikan. Antibisa ular dapat berefek setelah beberapa hari atau jika terdapat abnormalitas hemostasis, dalam 2 minggu atau lebih. Dapat disarankan agar antibisa ular tetap diberikan selama terdapat gangguan hemostasis. Antibisa ular masih kontroversi dalam hal efeknya terdapat nekrosis, namun beberapa bukti dapat menunjukkan bahwa antibisa ular dapat mengurangi nekrosis jika langsung diberikan dalam beberapa jam pertama setelah gigitan.

Anti-bisa ular diberikan dengan 2 cara yaitu:

1. Kecepatan kurang dari $2 \mathrm{~mL}$ per menit dengan syringe pump.

2. Infus intravena: antibisa ular dilarutkan dalam 200-500 
salin isotonik atau dextrose $5 \%$ dan diberikan dengan tetesan yang konstan dalam 1 jam.

Dalam pemberian antibisa ular, perlu selalu disiapkan epinefrin untuk terapi emergensi apabila terjadi reaksi alergi terhadap antibisa ular.

\section{KESIMPULAN}

Dilaporkan dua kasus gigitan ular golongan Viperidae dengan manifestasi klinis yang mirip seperti mual dan muntah, nyeri, kebiruan, bengkak di tempat gigitan berbisa, dan penurunan kesadaran. Pada pemeriksaan didapatkan gangguan kesadaran, anemia, perdarahan saluran kemih, dan koagulopati yang cukup berat.

\section{DAFTAR PUSTAKA}

1. Kasturiratne, A., Wickremasinghe, A. R., de Silva, N.,et al., The global burden of snakebite: A literature analysis and modelling based on regional estimates of envenoming and deaths. PLoS Med. 5, 1591-1604 (2008).

2. Warrell, D. A. WHO/SEARO Guidelines for the clinical management of snake bites in the
Southeast Asian region. Southeast Asian J. Trop. Med. Public Health 30 Suppl 1, 1-85 (1999).

3. Laraba-Djebari, F. \& Fatah, C. Pathophysiological and Pharmacological Effects of Snake Venom Components: Molecular Targets. J. Clin. Toxicol. 4, 190 (2014).

4. Sontichai, W., Reungrongrat, S., Narongchai, P., et al., Neurological Involvement and Hepatocellular Injury Caused by a Snake With Hematotoxin Envenomation. Wilderness \& Environmental Medicine (2015).

5. Peterson, M. E. Snake Bite: Pit Vipers. Clin. Tech. Small Anim. Pract. 21, 174-182 (2006).

6. Stewart, M. E., Greenland, S. \& Hoffman, J. R. First-aid treatment of poisonous snakebite: Are currently recommended procedures justified? Ann. Emerg. Med. 10, 331-335 (1981).

7. Sentra Informasi Keracunan Nasional BPOM.Penatalaksanaan Keracunan Akibat Gigitan Ular Berbisa.

http://www2.pom.go.id/public/ siker/desc/ produk/racunularberbisa.pdf. Diakses 30 November 2016. 